Прима М. В.

(0000-0002-8363-1929);

Мулявка А. С.

(0000-0002-3113-0719);

Леонтович С. П. канд. екон. наук

(0000-0002-0393-1869);

Дергільова О. В., канд. техн. наук, ст. наук. співроб.

(0000-0003-3916-1744)

Центр воєнно-стратегічних досліджень Національного університету оборони України імені Івана Черняховського, Київ

\title{
Аналіз досвіду провідних країн світу щодо планування спроможностей сил оборони із застосуванням автоматизації процесів ресурсного забезпечення
}

Резюме: У статті проведено аналіз досвіду провідних країн світу щодо планування спроможностей, розподілу ресурсів. Розглядається питання застосування процесів автоматизації різних ланок управління ресурсним забезпеченням.

Ключеві слова: автоматизація; система; ресурси; планування на основі спроможностей.

Постановка проблеми. Питання застосуванням автоматизації процесів ефективного розподілу виділеного державою ресурсного забезпечення розкрито фінансового ресурсу між складовими сил оборони набуває особливої актуальності в умовах застосування частин і підрозділів для вирішення бойових і спеціальних завдань на Сході України, а також в умовах зростання рівня загроз з боку Росії [1-3]. Досвід проведення Антитерористичної операції, операції Об'єднаних сил на Сході України показав, що рівень функціонування системи ресурсного забезпечення є недосконалим. Нові види озброєння та військової техніки, способи ведення бойових дій, швидкість зростання потреб сил оборони, висувають нові вимоги до ресурсного забезпечення.

У такій ситуації планування спроможностей сил оборони із змінами вимог до системи ресурсного забезпечення 3 врахуванням застосування нових способів дій, максимального використання наявних сил та засобів у швидкому темпі, можливості автоматизації процесів ресурсного забезпечення різних ланок управління при виконанні міжвидових операцій складових сил оборони, є актуальним науковим і практичним завданням.

Аналіз останніх досліджень i публікацій свідчить, що система планування на основі спроможностей на цей час використовується в оборонному плануванні провідних країн світу. Водночас, питанням матеріально-технічного забезпечення військ присвячені наукові дослідження зарубіжних та українських науковців: Дж.Коула, М. Ліндерса, І І. Романченка, О. Хазановича, В. Ніколайчука, А. Сухорукова, Л. Фролова, Н. Чухрай та інших. Однак питання забезпечення спроможностей сил оборони із недостатньо $[4,5]$.

Кількість автоматизованих систем Збройних Сил України, які успішно доведені до стадії прийняття на озброєння та експлуатації незначна [4], хоча роботи в цьому напрямі ведуться постійно. Автоматизовані системи, які створені на замовлення Міністерства оборони України та Збройних Сил України, нині перебувають на різних стадіях життєвого циклу, що зумовлює продовження процесу їх удосконалення за умов використання для забезпечення спроможностей сил оборони.

Метою статті є аналіз досвіду провідних країн світу щодо забезпечення спроможностей сил оборони із застосуванням автоматизації процесів ресурсного забезпечення.

Виклад основного матеріалу. На сьогодні планування орієнтоване на спроможності (далі - ПОС) є стандартною процедурою для планування розвитку національних збройних сил та невід'ємною складовою трансформаційних процесів у країнах НАТО. Зміст процесу ПОС складається 3 кілька взаємопов'язаних між собою кроків: аналізу стратегічних вказівок i політичної стратегії держави; відпрацювання сценаріїв застосування ЗС; визначення завдань військам (силам) відповідно до можливих сценаріїв застосування; обгрунтування вимог до спроможностей військ (сил) на визначений період; визначення нестач спроможностей; оптимальний розподіл ресурсів.

Процес планування на основі спроможностей не має універсального визначення, але більшість практиків погодяться 3 таким: "ПОС - це планування в 
умовах невизначеності для забезпечення відповідних спроможностей, які підходять для широкого спектра сучасних умов і викликів, у межах економічних можливостей держави". ПОС це системний підхід, який спрямований на виявлення та надання рекомендацій щодо найприйнятніших за критерієм “вартістьефективність" варіантів розвитку військ (сил) для задоволення пріоритетів національної безпеки.
Метою планування спроможностей $є$ забезпечення необхідного рівня обороноздатності держави шляхом визначення перспектив їх розвитку 3 урахуванням характеру реальних i потенційних загроз у воєнній сфері та економічних можливостей держави.

На рис. 1 наведено розподіл видатків на потреби складових сил оборони України на 2019 рік.

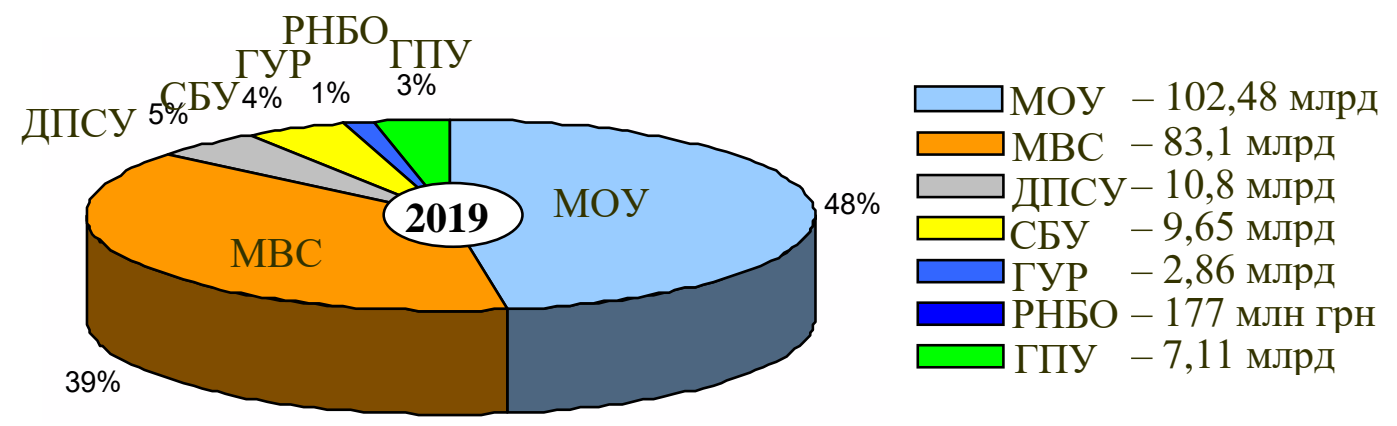

Рис. 1. Бюджет силових структур та відомств на 2019 рік

Кожна складова сил оборони планує розвиток спроможностей власних підрозділів у межах виділених асигнувань. Наприклад, у Міністерстві оборони України (МО України) та Збройних Сил України (ЗС України) це здійснюється за допомогою оборонного планування, яке має забезпечувати здатність координувати використання бюджетних коштів i матеріальних ресурсів, спрямованих на розвиток спроможностей, зокрема тих, що передбачені для виконання програм (планів) та реалізації проєктів, і навіть міжнародних. Крім того, одним із завдань оборонного планування, $\epsilon$ врахування заходів операції об'єднаних сил.

На сьогодні в МО України та ЗС України немає процедури визначення обсягу ресурсного забезпечення, необхідного для планування об'єднаних спроможностей складових сил оборони. Проте досвід планування ресурсного забезпечення міжвидових об'єднань є у воєнному відомстві США.

Питання забезпечення планування об'єднаних спроможностей складових сил оборони США для задоволення потреб міжвидового ведення збройної боротьби виникло раніше, оскільки у збройних силах США є певні зобов'язання перед країнамипартнерами НАТО. Армії провідних європейських країн займаються бойовою підготовкою, як i належить, у пунктах постійної дислокації чи на базах. Відповідно до цих потреб організоване й ресурсне забезпечення. Коли ж йдеться про ухвалення рішення щодо застосування підрозділів, починає працювати інша система забезпечення [7]: створюється об'єднане оперативне командування, якому підпорядковується частини 3 різних видів i родів військ. Цей орган планує операцію та іï ресурсне забезпечення. Наприклад, бюджет операції “Буря в пустелі” становив близько 3 млрд доларів. Кошти на іiі проведення виділялися окремо, а не з рахунків утримання частин, які брали в ній участь.

Командування збройних сил США приділяє важливе значення вдосконаленню системи ресурсного забезпечення військ. До того ж вважається, що від того, наскільки швидко, та 3 якою повнотою органи тилу впораються зі своїми завданнями щодо забезпечення військ усім необхідним, значною мірою залежатиме виконання тактичних, оперативних і стратегічних планів. Останнім часом у зв'язку 3 подіями гібридного типу, для розв'язанняння міждержавних проблем американське командування приділяє значну увагу поліпшенню організаційної структури частин і підрозділів матеріального, технічного та медичного забезпечення, органів управління тилом, а також розробленню та практичній перевірці нових принципів і способів постачання військ.

Основна мета проведених організаційних заходів полягає в тому, щоб централізувати управління тилом у всіх ланках i спростити систему забезпечення військ. Одним зі шляхів розв'язанняння поставленого питання $є$ автоматизація процесів ресурсного 
забезпечення військ у всіх ланках (табл. 1) [7], де вирішуються завдання обліку і розподілу матеріальних і технічних засобів, контроль за ix переміщенням, управління технічним обслуговуванням і ремонтом в частинах i підрозділах, на складах i в спеціальних ремонтних підрозділах.

\begin{tabular}{|c|c|}
\hline Назва системи & Призначення \\
\hline $\begin{array}{l}\text { ALPHA - AMC Logistics Program } \\
\text { Hardcore Automated }\end{array}$ & $\begin{array}{l}\text { Автоматизоване управління постачанням, технічним обслуговуванням і } \\
\text { ремонтом, приймання, облік та розподіл предметів постачання, контроль } \\
\text { запасів матеріальних засобів, складання перспективних планів постачання, а } \\
\text { також ведення фінансової звітності }\end{array}$ \\
\hline $\begin{array}{l}\text { SPEEDEX - System-Wide Project for } \\
\text { Electronic Equipment at Depots- } \\
\text { Extended }\end{array}$ & $\begin{array}{l}\text { Автоматизація процесів обробки даних матеріально-технічного } \\
\text { забезпечення на базових складах континентальної частини; } \\
\text { забезпечення стандартизованих процесів складських операцій з обліку, } \\
\text { розподілу, транспортування матеріальних і технічних засобів; } \\
\text { облік процесів технічного обслуговування і ремонту техніки, що } \\
\text { зберігається на складах; } \\
\text { розрахунок грошового забезпечення особового складу центрів ресурсного } \\
\text { забезпечення, витрат на внутрішньоскладські операції; } \\
\text { облік особового складу центрів ресурсного забезпечення; } \\
\text { забезпечення посадових осіб різних категорій інформацією про наявність і } \\
\text { видачу майна та коштів, витрат на внутрішньоскладські операції та ін. }\end{array}$ \\
\hline $\begin{array}{l}\text { CS.3 - Combat Service Support } \\
\text { System }\end{array}$ & $\begin{array}{l}\text { Управління ресурсним забезпеченням військ; } \\
\text { облік процесів технічного обслуговування і ремонту бойової техніки, } \\
\text { адміністративно-господарське управління; } \\
\text { облік і комплектування особового складу; } \\
\text { облік процесів забезпечення всіх видів перевезень в армійському, } \\
\text { корпусному і дивізійних ланках управління }\end{array}$ \\
\hline DLOGS - Division Logistics System & $\begin{array}{l}\text { Автоматизоване управління завдань обліку, контролю і розподілу ресурсів у } \\
\text { дивізійній ланці }\end{array}$ \\
\hline $\begin{array}{l}\text { SAMMIS - Semi Automated Material } \\
\text { Management Information System }\end{array}$ & $\begin{array}{l}\text { Автоматичне надання командирам різних ступенів щотижневих звітів про } \\
\text { технічний стан бойової техніки; } \\
\text { контроль процесів експлуатації озброєння, техніки та різного обладнання } 3 \\
\begin{array}{l}\text { метою своєчасного внесення необхідних змін у порядок проведення } \\
\text { ремонтних робіт }\end{array}\end{array}$ \\
\hline $\begin{array}{l}\text { DSU/GSU (Direct Support Unit / } \\
\text { General Support Unit) }\end{array}$ & $\begin{array}{l}\text { Автоматизоване управління обліком запасів матеріальних засобів у режимі } \\
\text { реального часу частин і підрозділів загального і безпосереднього } \\
\text { забезпечення }\end{array}$ \\
\hline
\end{tabular}

Автоматизована система ресурсного забезпечення військ США працює через обчислювальні центри армійського, корпусного і дивізійного ланок управління.

За конструкцією обчислювальних центрів i периерій обен центрів і периферійних пристроїв введення-виведення даних $\epsilon$ мобільною, електронне обладнання розміщується в спеціальних фургонах (кількість фургонів залежить від ланки управління), які транспортуються тягачами. Кожен обчислювальний центр вирішує певну кількість інформаційних і розрахункових завдань щодо ресурсного забезпечення військ. Програми разом із необхідними вихідними даними зберігаються у зовнішніх пристроях пам'яті. Вихідні дані за певними категоріями групуються в масиви даних, кожен 3 яких має свій код. Інформаційні масиви постійно оновлюються. Для цього дані у вигляді заздалегідь встановлених повідомлень надходять від периферійних пристроїв введення-виведення даних 3 інших обчислювальних центрів. У кожному повідомленні вказуються категорія терміновості, вид інформації (до якого масиву повинні належати дані) та інші службові ознаки. На основі накопичених інформаційних масивів забезпечується видача необхідних даних посадовим особам у вигляді щоденних, тижневих, місячних, квартальних i річних зведень і звітів.

У дивізійній ланці працює центр управління постачанням, основу функціонування якого становить єдиний інформаційний масив на базі ЕОМ “Юнивак1005”, а також групи постачання, які, як правило, призначені для обслуговування однотипних частин і підрозділів, що входять до складу дивізії (інженерних, технічного обслуговування, танкових, піхотних та ін.).

$$
\text { Центр управління постачанням }
$$
дивізійної ланки поєднаний з батальйонною секцією постачання. До обов'язків батальйонної секції постачання входить приймання заявок від підлеглих рот, їх аналіз, узагальнення та передача даних для введення в єдиний інформаційний масив дивізійного центру управління постачанням. У дивізійний центр управління постачанням 3 певною 
періодичністю надходить оновлена інформація про стан ресурсного забезпечення підпорядкованих батальйону рот.

За допомогою системи щомісяця видається стандартний Звіт, у якому зазначаються номенклатура предметів постачання, їх кількість відповідно до штатнопосадового розкладу і табеля майна, зміни в нормах постачання, кількість предметів постачання, що знаходяться в підрозділі, кількість і типи предметів постачання понад або менше встановленої норми та інші дані. На підставі цих даних батальйонна секція готує щотижневі, щомісячні та щоквартальні повідомлення про стан ресурсного забезпечення в батальйоні. Крім того, в установленому порядку секція інформує командира батальйону про стан постачання в підлеглих ротах.

$\mathrm{y}$ ротах (батареях) за постачання відповідає командир роти. Безпосередньо отриманням і видачею предметів постачання займається сержант, а командир роти контролює отримання, списання та наявність майна i техніки в роті на підставі Звіту, щомісяця. Основою для формування і видачі такого документа $\epsilon$ дані, що зберігаються в єдиному інформаційному масиві дивізійного центру управління постачанням.

У Звіті містяться відомості про номенклатуру предметів постачання, їх наявність i призначену кількість, зміни (надходженнях нових предметів постачання або списання старих) і дату, коли відбулися ці зміни, й інші відомості. Усі подібні Звіти обробляються за допомогою ЕОМ на прикінці місяця, а результати обробки вводяться в єдиний інформаційний масив, де для кожної роти виділена відповідна зона пам'яті.

Мобільна автоматизована система обліку запасу матеріальних засобів DSU/GSU (Direct Support Unit/General Support Unit) нині застосовується в частинах і підрозділах загального i безпосереднього забезпечення. Система забезпечує обробку даних про 30 тис. видів предметів постачання, іiі продуктивність становить майже 20 тис. заявок на місяць [7].

Отже, усі ланки американських сухопутних військ широко застосовують планування спроможностей разом 3 автоматизацією процесів ресурсного забезпечення. Командування армії США вважає, що в майбутній війні це дасть змогу оперативніше i ефективніше вирішувати завдання постачання частин і підрозділів усім необхідним.

Досвід проведення АТО показав, що стандарти забезпечення ЗС України застаріли i потребують оновлення. Армія не в змозі ефективно управляти ресурсним забезпечення, вести облік і контролювати його рух у сучасних умовах. Більш того, у разі інтенсивного ведення бойових дій, участі в них підрозділів складових сил оборони та ручне управління процесами ресурсного забезпечення ставить питання щодо виконання завдань під час збройного конфлікту.

Завданнями 1.4.6 i 1.4 .8 Матриці досягнення стратегічних цілей i виконання основних завдань оборонної реформи визначено завдання 3 впровадження автоматизованої системи із системою управління оборонними ресурсами сил оборони відповідно до стандартних угод НАТО, створення єдиної інформаційної системи управління оборонними ресурсами, матеріально-технічним забезпеченням та іншими видами забезпечення. Об'єктивні потреби у виконанні постійно зростаючої кількості завдань можуть бути стимулюючим фактором для пошуку нових шляхів забезпечення розвитку 3С, нових технологій, використання досвіду провідних країн світу тощо.

Отже, можливо взяти досвід США та на етапі розподілу оборонного бюджету держави між складовими сил оборони (рис. 1). створити окрему програму фінансування об'єднаного оперативного командування (об'єднаних сил оборони). Розподіл коштів цієї програми здійснювати враховуючі у відсотковому еквіваленті участь складових сил оборони в операції Об'єднаних сил. Таким же чином необхідно організовувати ресурсне забезпечення сил оборони 3 розмежуванням забезпечення сил і засобів у пунктах постійної дислокації та у процесі їх безпосередньої участі в операціях Об'єднаних сил.

Автоматизація процесів ресурсного забезпечення на різних ланках управління дасть змогу сприяти вирішенню питання організації взаємодії органів управління сил оборони усіх рівнів, скоротить час на одержання і всебічну оцінку відомостей про матеріальні засоби на всіх етапах їх руху, спростити та пришвидшити процеси забезпечення, що у майбутньому дасть змогу поліпшити взаємодію 3 аналогічними системами провідних країн світу.

Висновки та напрями подальших досліджень. Аналіз досвіду планування ресурсного забезпечення в збройних силах США показав за доцільне використання їх підходів щодо фінансового забезпечення міжвидових операцій та автоматизації 
процесів ресурсного забезпечення військ у всіх ланках.

\section{СПИСОК ВИКОРИСТАНОЇ ЛІТЕРАТУРИ}

1. Малков С. Ю., Ковалев В. И., Коссе Ю. В. К вопросу об определении оптимальной величины оборонных расходов государства. Стратегическая стабильность, 2007. № 2. С. 72-76.

2. Масловский С. С. Оборонное планирование на основе возможностей с учётом долгосрочной Российской угрозы. URL: https://censor.net.ua/news/440093/oboronnoe

planirovanie ukrainy uchityvaet dolgosrochnuyu rossiyiskuyu ugrozu genshtab. (дата звернення 21.11.2019).

3. Т. Тагарєв., Основні питання програмноорієнтовного управління оборонними ресурсами. Наука і оборона. Київ, 2006. № 3. С. 18-24.
4. Романченко І. С., Шуєнкін В. О. Погляди на розвиток системи матеріально-технічного забезпечення Збройних Сил України. Наука $i$ оборона. Київ, 2007. №4. С.36-39.

5. Хазанович О. I. Система матеріально-технічного забезпечення: Ретроспектива розвитку та напрями удосконалення. Наука і оборона. Київ, 2007. № 1. С. 27-31.

6. Закалад М. А., Утюшев М. К., Бобров С. В. Підходи до автоматізації процесів логістичного забезпечення Збройних Сил України. Збірник наукових праць Центру воєнно-стратегічних досліджень Національного університету оборони Украӥни імені Івана Черняховського. Київ, 2018. № 3(64), URL : https://nuou.org.ua/assets/journals/ zbirnyk_cvsd/zb-3-64-2018.pdf.

7. Автоматизация процессов МТО сухопутных войск США URL: http://www.zvo.su/suhoputnyevoyska/avtomatizaciya-processov-mto-suhoputnyhvoysk-ssha.html/.

Стаття надійшла до редакційної колегії 07.11.2019

Прима М. В.;

Мулявка А. С.;

Леонтович С. П., канд. екон. наук;

Дергилёва Е. В. канд. техн. наук, ст. науч. сотр.

Центр военно-стратегических исследований Национального университета оборони Украины имени Ивана Черняховского, Киев

\footnotetext{
Анализ опыта ведущих стран мира по планированию возможностей сил обороны с учетом автоматизации процессов ресурсного обеспечения

Резюме. В статье проведен анализ опыта ведущих стран мира по планированию возможностей, распределения ресурсов. Рассматривается вопрос применения процессов автоматизации различных звеньев управления ресурсным обеспечением.

Ключевые слова: автоматизация; система; ресурсы; планирование на основе возможностей.
}

\section{Prima;}

\section{A. Muliavka;}

S. Leontovych, PhD (Economic);

E. Dergileva, PhD (Technical), senior researcher

Center for Military and Strategic Studies of the National Defence University of Ukraine named after Ivan Cherniakhovskyi, Kyiv

Analysis of the experience of the leading countries in capability based planning of the defense forces, taking into account the automation of resource support processes

Resume. The article analyzes the experience of the leading countries of the world in planning opportunities, resource allocation. The question of the application of automation processes of various links of resource management is considered.

Keywords: automation; system; resources; capability-based planning. 